Article

\title{
The Structural Dimorphism of Lanthanum Oxide Fluoride Selenide $\mathrm{La}_{2} \mathrm{OF}_{2} \mathrm{Se}$
}

\author{
Constantin Buyer, Hagen Grossholz and Thomas Schleid * \\ Institute for Inorganic Chemistry, University of Stuttgart, Pfaffenwaldring 55, D-70569 Stuttgart, Germany \\ * Correspondence: schleid@iac.uni-stuttgart.de; Tel.: +49711/685-64240
}

Received: 17 July 2019; Accepted: 16 August 2019; Published: 21 August 2019

\begin{abstract}
The new colorless lanthanum oxide fluoride selenide $\mathrm{La}_{2} \mathrm{OF}_{2} \mathrm{Se}$ could be synthesized via solid-state reactions in two different structure types. Lamellar crystals of $\mathrm{A}-\mathrm{La}_{2} \mathrm{OF}_{2} \mathrm{Se}$ were obtained from mixtures of $\mathrm{La}, \mathrm{LaF}_{3}, \mathrm{La}_{2} \mathrm{O}_{3}$ and $\mathrm{Se}$ in molar ratios of 2:2:1:3 with $\mathrm{NaCl}$ as flux for seven days in silica-protected sealed tantalum capsules at $850{ }^{\circ} \mathrm{C}$. Needle-shaped crystals of B- $\mathrm{La}_{2} \mathrm{OF}_{2} \mathrm{Se}$ emerged from reactions of the same educt mixtures in molar ratios of 6:4:4:9 scheduled to produce $\mathrm{La}_{6} \mathrm{O}_{4} \mathrm{~F}_{4} \mathrm{Se}_{3}$ with CsI as flux for four days in niobium ampoules at $700{ }^{\circ} \mathrm{C}$. The A-type form of $\mathrm{La}_{2} \mathrm{OF}_{2} \mathrm{Se}$ crystallizes in the trigonal space group $R \overline{3} m$ with $a=418.13$ (3) and $c=4478.2(4) \mathrm{pm}$ for $Z=6$, whereas the B-type form is hexagonal (space group: $P 6_{3} / m$ ) with $a=1396.82(9)$ and $c=401.08(3) \mathrm{pm}$ for $Z=6$. The crystal structure of A- $\mathrm{La}_{2} \mathrm{OF}_{2} \mathrm{Se}$ shows a close relationship to the fluoride-free $\mathrm{La}_{2} \mathrm{O}_{2} \mathrm{Se}$ and the oxygen-free $\mathrm{La}_{2} \mathrm{~F}_{4} \mathrm{Se}$. It can even be discussed as 1:1 intergrowth variety, since it contains the $\left[\mathrm{LaO}_{4} \mathrm{Se}_{3}\right]^{11-}$ and $\left[\mathrm{LaF}_{7} \mathrm{Se}_{3}\right]^{10-}$ polyhedra typical for the ternaries. $\mathrm{B}-\mathrm{La}_{2} \mathrm{OF}_{2} \mathrm{Se}$ appears to be structurally very similar to $\mathrm{La}_{6} \mathrm{O}_{2} \mathrm{~F}_{8} \mathrm{Se}_{3}$ in displaying $\left[\mathrm{LaO}_{3} \mathrm{FSe}_{4}\right]^{12-}$ and $\left[\mathrm{LaOF}_{6} \mathrm{Se}_{2}\right]^{9-}$ polyhedra. With 6.039 versus $6.036 \mathrm{~g} / \mathrm{cm}^{3}$ the B-type form of $\mathrm{La}_{2} \mathrm{OF}_{2} \mathrm{Se}$ is slightly denser than the A-type variant.
\end{abstract}

Keywords: lanthanum oxide fluoride selenides; polymorphism; X-ray diffraction; crystal structure; rare-earth metal compounds

\section{Introduction}

Rare-earth metal sesquiselenides $\left(R E_{2} \mathrm{Se}_{3}, R E=\mathrm{Sc}, \mathrm{Y}, \mathrm{La}, \mathrm{Ce}-\mathrm{Lu}\right)$ come in three modifications, which offer coordination numbers of eight (C- or $\mathrm{Ce}_{2} \mathrm{~S}_{3}$-type structure, $R E=\mathrm{La}-\mathrm{Nd}, \mathrm{Sm}, \mathrm{Tb}, \mathrm{Gd}, \mathrm{Ho}$, Tm; cubic, $I \overline{4} 3 d$ ) [1-20], seven (U- or $\mathrm{U}_{2} \mathrm{~S}_{3}$-type structure, $R E=\mathrm{Sm}-\mathrm{Er}$; orthorhombic, Pnma) [5,16,21-25] and six (Z- or $\mathrm{Sc}_{2} \mathrm{~S}_{3}$-type structure $R E=\mathrm{Sc}, \mathrm{Y}, \mathrm{Eu}, \mathrm{Tb}, \mathrm{Ho}-\mathrm{Lu}$; orthorhombic, Fddd) [3,17,24,26-31] for the $R E^{3+}$ cations, reflecting the consequences of the lanthanoid contraction. They are dark red or black substances and thus not suitable to serve as host materials for luminescent $\mathrm{Ln}^{3+}$ cations, such as $\mathrm{Eu}^{3+}$ or $\mathrm{Tb}^{3+}$, in order to harvest red or green light. This changes a lot, when one considers their derivatives with hard anions like $\mathrm{F}^{-}$or $\mathrm{O}^{2-}$. For the rare-earth metal(III) fluoride selenides (REFSe) tetragonal NdFSe with PbFCl-type structure $(P 4 / \mathrm{nmm})$ [32] and hexagonal LaFSe in $P 6_{3} / \mathrm{mmc}$ are known [33], both exhibiting C.N. $\left(R E^{3+}\right)=9$. With cerium there is a trigonal compound $(R \overline{3} m)$ of the composition $\mathrm{Ce}_{2} \mathrm{~F}_{4} \mathrm{Se}$ in the literature providing a tenfold coordination sphere for $\mathrm{Ce}^{3+}$ [34], while HoFSe and ErFSe adopt orthorhombic structures in Pnma with coordination numbers between six and eight for the respective $R E^{3+}$ cations [35-37]. For YFSe, different orthorhombic polymorphs have also been reported, but even monoclinic ones $\left(P 2_{1} / \mathrm{m}\right)$ can be found [37-40]. If oxygen is added to the rare-earth metal(III) selenides, compounds with the compositions $R E_{10} \mathrm{OSe}_{14}\left(R E=\mathrm{La}\right.$, Ce-Nd; tetragonal, $I_{1} /$ acd $)$ [41,42], $R E_{2} \mathrm{OSe}_{2}\left(R E=\mathrm{Pr}\right.$; monoclinic, $P 2_{1} / c$ [42]; $R E=\mathrm{Gd}$ : orthorhombic; Pnma [43]) and $R E_{2} \mathrm{O}_{2} \mathrm{Se}(R E=\mathrm{La}$, $\mathrm{Pr}, \mathrm{Nd}, \mathrm{Sm}, \mathrm{Gd}, \mathrm{Ho}, \mathrm{Er}, \mathrm{Yb}$; trigonal, $\left.P 2_{1} / m 1\right)[42,44]$ are known. The richer in oxygen these oxide selenides get, the brighter their color becomes, so that $\mathrm{Y}_{2} \mathrm{O}_{2} \mathrm{Se}: \mathrm{Ln}^{3+}(\mathrm{Ln}=\mathrm{Ce}-\mathrm{Nd}, \mathrm{Sm}-\mathrm{Yb})$ even shows luminescence [45]. By adding both oxygen and fluorine as $\mathrm{O}^{2-}$ or $\mathrm{F}^{-}$to the RE/Se systems tetragonal 
$\mathrm{Ho}_{3} \mathrm{OFSe}_{3}$ (I4/mmm) [46], orthorhombic $\mathrm{Ho}_{3} \mathrm{OF}_{3} \mathrm{Se}_{2}$ (Ccce) [46], orthorhombic $\mathrm{Ce}_{6} \mathrm{O}_{4} \mathrm{~F}_{4} \mathrm{Se}_{3}$ (Pnma) [47] and tetragonal $\mathrm{Nd}_{5} \mathrm{OF}_{5} \mathrm{Se}_{4}(\mathrm{I} / \mathrm{mmm})$ [36] are found as singularities so far, but several members from the series $R E_{6} \mathrm{O}_{2} \mathrm{~F}_{8} \mathrm{Se}_{3}$ with $R E=\mathrm{La}-\mathrm{Nd}$ and $R E_{2} \mathrm{OF}_{2} \mathrm{Se}$ with $R E=\mathrm{Nd}, \mathrm{Sm}, \mathrm{Gd}-\mathrm{Ho}$ [48] occur. In the analogous sulfide systems the hexagonal $R E_{6} \mathrm{O}_{2} \mathrm{~F}_{8} \mathrm{~S}_{3}$ series with $R E=\mathrm{La}-\mathrm{Nd}, \mathrm{Sm}, \mathrm{Gd}$ [49] also exists, but there is an additional one for the formula type $R E_{3} \mathrm{OF}_{5} \mathrm{~S}$ with $R E=\mathrm{Y}, \mathrm{Nd}, \mathrm{Sm}, \mathrm{Gd}-\mathrm{Ho}$ [50-52] showing similar structural features. Despite this difference further analogies refer to compounds with the composition $R E_{3} \mathrm{OF}_{3} \mathrm{~S}_{2}$ with $R E=\mathrm{La}, \mathrm{Ce}, \mathrm{Er}[53,54]$ and $R E_{3} \mathrm{OFS}_{3}$ with $R E=\mathrm{Er}$ [54]. In our ongoing efforts to elucidate the $R E F_{3} / R E_{2} \mathrm{O}_{3} / R E_{2} \mathrm{Se}_{3}$ systems, we were now able to synthesize two modifications of a lanthanum oxide fluoride selenide with the formula $\mathrm{La}_{2} \mathrm{OF}_{2} \mathrm{Se}$.

\section{Materials and Methods}

Both forms of $\mathrm{La}_{2} \mathrm{OF}_{2}$ Se were synthesized by mixing lanthanum powder (La: ChemPur, $99.9 \%$, company, city, country), lanthanum trifluoride powder $\left(\mathrm{LaF}_{3}\right.$ : ChemPur, $99.9 \%$, company, Karlsruhe, Germany), lanthanum sesquioxide powder $\left(\mathrm{La}_{2} \mathrm{O}_{3}\right.$ : ChemPur, $99.9 \%$ company, city, country) and selenium powder (Se: Alfa-Aesar, $99.999 \%$ company, city, country) (in sum: about $300 \mathrm{mg}$ ) in a glove box under argon atmosphere. For A-type $\mathrm{La}_{2} \mathrm{OF}_{2} \mathrm{Se}$ the stoichiometric molar ratio 2:2:1:3 was used as well as an excess of about $500 \mathrm{mg}$ sodium chloride powder ( $\mathrm{NaCl}$ : ChemPur, $99.9 \%$ company, city, country) to work as the fluxing agent. After heating this mixture at $850{ }^{\circ} \mathrm{C}$ for seven days in a sealed tantalum capsule, protected by an evacuated secondary silica ampoule, colorless platelets with triangular cross-section were obtained. B-type $\mathrm{La}_{2} \mathrm{OF}_{2} \mathrm{Se}$ emerged as colorless needles from the same educt mixture in molar ratio of 6:4:4:9, because the target compound was $\mathrm{La}_{6} \mathrm{O}_{4} \mathrm{~F}_{4} \mathrm{Se}_{3}$ in analogy to $\mathrm{Ce}_{6} \mathrm{O}_{4} \mathrm{~F}_{4} \mathrm{Se}_{3}$ [47]. This mixture was charged with $300 \mathrm{mg}$ cesium iodide powder (CsI: ChemPur, $99.9 \%$ ) as fluxing agent and heated at $700{ }^{\circ} \mathrm{C}$ for four days in a sealed niobium tube encapsulated into an evacuated silica ampoule. After cooling down to room temperature directly with $5 \mathrm{~K} / \mathrm{h}$ in the $\mathrm{NaCl}$-flux case and to $540{ }^{\circ} \mathrm{C}$ with $3 \mathrm{~K} / \mathrm{h}$ and $\mathrm{CsI}$ as flux before shutting down the furnace, washing with water, ethanol and ether removed the alkali-metal halides and left the air- and water-stable (but not phase-pure) samples of $\mathrm{La}_{2} \mathrm{OF}_{2} \mathrm{Se}$ behind. For B-type $\mathrm{La}_{2} \mathrm{OF}_{2} \mathrm{Se}$ the applied stoichiometry leads to $\mathrm{La}_{2} \mathrm{O}_{2} \mathrm{Se}$ [44] besides B- $\mathrm{La}_{2} \mathrm{OF}_{2} \mathrm{Se}$ according to $6 \mathrm{La}+4 \mathrm{LaF}_{3}+4 \mathrm{La}_{2} \mathrm{O}_{3}+9 \mathrm{Se} \rightarrow 2 \mathrm{La}_{2} \mathrm{OF}_{2} \mathrm{Se}+\mathrm{La}_{2} \mathrm{O}_{2} \mathrm{Se}$.

For the data collections enabling $\mathrm{X}$-ray structure analyses a IPDS diffractometer (Stoe and Cie) for A-type $\mathrm{La}_{2} \mathrm{OF}_{2} \mathrm{Se}$ and a $k-C C D$ diffractometer (Bruker-Nonius) for B-type $\mathrm{La}_{2} \mathrm{OF}_{2} \mathrm{Se}$ with graphite-monochromatized Mo-K $\alpha$ radiation $(\lambda=71.07 \mathrm{pm})$ was used. The collected data were processed with the program SHELX-97 [55,56] for the structure solutions and refinements. Crystallographic data, atomic positions, equivalent isotropic displacement coefficients, selected interatomic distances and angles can be found in Tables 1-5, while Table 6 displays the motifs of mutual adjunction for both forms of $\mathrm{La}_{2} \mathrm{OF}_{2} \mathrm{Se}$. The CIF data sheets of the crystal-structure investigations are available under CSD-1919109 for A- $\mathrm{La}_{2} \mathrm{OF}_{2} \mathrm{Se}$ and CSD-1919110 for B-La $\mathrm{OF}_{2} \mathrm{Se}$ from the Fachinformationszentrum (FIZ) Karlsruhe, D-76344 Eggenstein-Leopoldshafen, Germany (e-mail: crysdata@fiz-karlsruhe.de) (or see Supplementary Materials).

For the determination of the element ratios in $\mathrm{B}$-type $\mathrm{La}_{2} \mathrm{OF}_{2} \mathrm{Se}$ an electron-beam microprobe technique has been applied. After performing X-ray diffraction, the single crystal was placed on a conductive carbon pad and vaporized with carbon. This setup entered the electron-beam microprobe (Cameca SX-100), which is equipped with an energy-dispersive X-ray spectrometer (EDXS). The measured energy-dispersive $X$-ray spectrum with its assigned peaks is shown in later in the running text and the calculated mass content compared to theoretical mass content of each element under consideration can be taken from Table 7 . 


\section{Results}

\subsection{Structure Description of A-Type $\mathrm{La}_{2} \mathrm{OF}_{2} \mathrm{Se}$}

The A-type and the B-type form of $\mathrm{La}_{2} \mathrm{OF}_{2}$ Se show markedly different crystal structures. A-type $\mathrm{La}_{2} \mathrm{OF}_{2} \mathrm{Se}$ crystallized in the trigonal space group $R \overline{3} m$ with $a=418.13(3)$ and $c=4478.2(4)$ pm $(c / a=10.710)$ for $Z=6$. Its crystal structure (Figure 1$)$ revealed a close relationship to the oxygen-free $\mathrm{La}_{2} \mathrm{~F}_{4}$ Se (trigonal, $R \overline{3} m ; a=417.86(2) \mathrm{pm}, c=2326.78(9) \mathrm{pm}, \mathrm{Z}=3$ ) $[33,57]$ on the one hand and the fluoride-free $\mathrm{La}_{2} \mathrm{O}_{2} \mathrm{Se}$ (trigonal, $P \overline{3} m 1 ; a=408.27(3) \mathrm{pm}, c=717.19(5) \mathrm{pm}, Z=1$ ) [44,58] on the other. As a consequence two crystallographically different positions for $\mathrm{La}^{3+}$ cations exist. The first one (La1) is surrounded by four $\mathrm{O}^{2-}$ and three $\mathrm{Se}^{2-}$ and anions to build an oxide-capped trigonal antiprism with $\mathrm{Se}^{2-}$ on the bottom and $\mathrm{O}^{2-}$ on the top (Figure 2a), without participation of any $\mathrm{F}^{-}$anion. The distance to the capping oxide anion is with $249 \mathrm{pm}$ a little larger than those to the oxygen atoms within the triangular face of the $\left[(\mathrm{La} 1) \mathrm{O}_{4} \mathrm{Se}_{3}\right]^{11-}$ polyhedron $\left(d\left(\mathrm{La}^{3+}-\mathrm{O}^{2-}\right)=247 \mathrm{pm}, 3 \times\right)$. The second $\mathrm{La}^{3+}$ cation (La2) is coordinated by seven $\mathrm{F}^{-}$and three $\mathrm{Se}^{2-}$ anions, which erect a quadruple-capped trigonal prism $\left[(\mathrm{La} 2)(\mathrm{F} 1)_{3}(\mathrm{~F} 2)_{4} \mathrm{Se}_{3}\right]^{10-}$ with $\mathrm{Se}^{2-}$ at the bottom, $(\mathrm{F} 2)^{-}$as the top cap, $(\mathrm{F} 2)^{-}$in the triangular top face and (F1) ${ }^{-}$capping the three side faces (Figure $2 \mathrm{~b}$ ). The distances from (La2) ${ }^{3+}$ to the capping $\mathrm{F}^{-}$ anions range between $242 \mathrm{pm}$ ( $3 \times$ to F1) and $245 \mathrm{pm}\left(1 \times\right.$ to F2), while the (La2) ${ }^{3+}-(\mathrm{F} 2)^{-}$distance to the top triangular face is $266 \mathrm{pm}(3 \times)$. The $\mathrm{O}^{2-}$ anion is surrounded by a tetrahedron of four (La1) ${ }^{3+}$ cations (Figure 2c) at distances of $247 \mathrm{pm}(3 \times)$ and $249 \mathrm{pm}(1 \times)$, whereas the $\mathrm{e}^{2-}$ anions has contact to six $\mathrm{La}^{3+}$ cations arranged as triangular antiprism with $3 \times \mathrm{La} 1$ at $317 \mathrm{pm}$ and $3 \times \mathrm{La} 2$ at $321 \mathrm{pm}$ distance (Figure 2f). The coordination sphere of (F1) ${ }^{-}$appeared triangularly planar by three $\mathrm{La}^{3+}$ cations $\left(d(\mathrm{~F} 1)^{-}-(\mathrm{La} 2)^{3+}=242 \mathrm{pm}\right)$, while as $(\mathrm{F} 2)^{-}$centers a tetrahedron (Figure $\left.2 \mathrm{~d}, \mathrm{e}\right)$ of four $\mathrm{La}^{3+}$ cations $\left(d(\mathrm{~F} 2)^{-}-(\mathrm{La} 2)^{3+}=245 \mathrm{pm}(1 \times), 266 \mathrm{pm}(3 \times)\right)$. Selected interatomic distances can be seen in detail in Table 4, while the fractional atomic coordinates and the $U_{\text {eq }}$ values are summarized in Table 2.

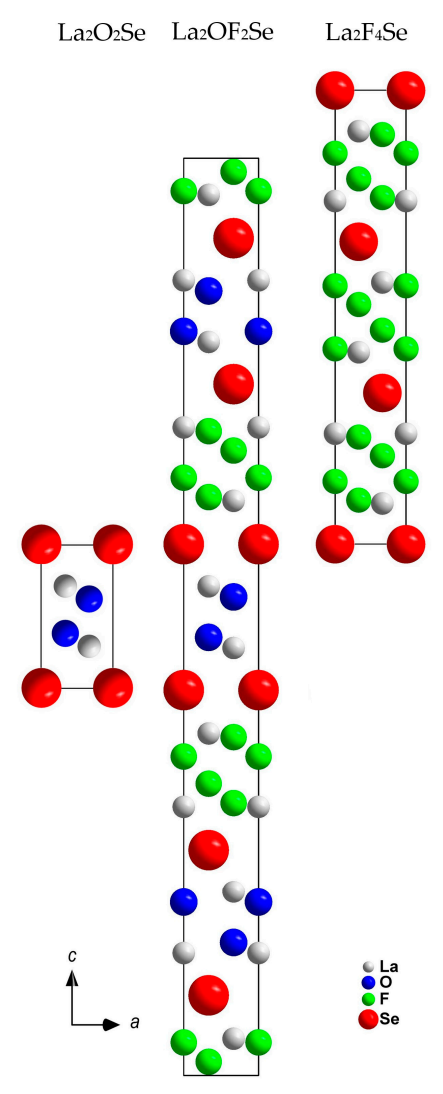

Figure 1. Comparison of the crystal structures of A-type $\mathrm{La}_{2} \mathrm{OF}_{2} \mathrm{Se}$ (mid) with $\mathrm{La}_{2} \mathrm{O}_{2} \mathrm{Se}$ (left) and $\mathrm{La}_{2} \mathrm{~F}_{4} \mathrm{Se}$ (right). 

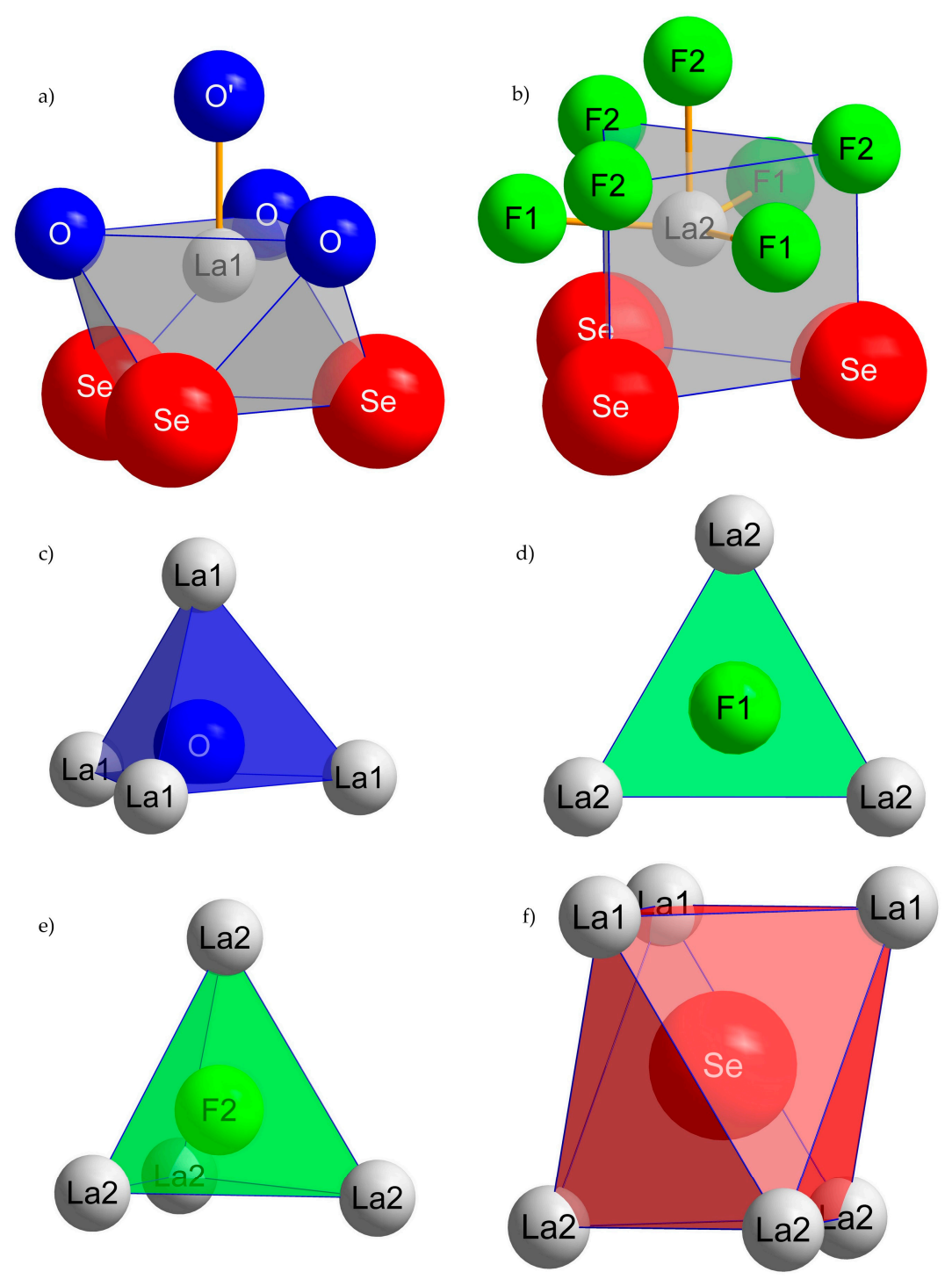

Figure 2. Coordination polyhedra in A-type $\mathrm{La}_{2} \mathrm{OF}_{2} \mathrm{Se}$.

\subsection{Structure Description of B-Type $\mathrm{La}_{2} \mathrm{OF}_{2} \mathrm{Se}$}

B-type $\mathrm{La}_{2} \mathrm{OF}_{2} \mathrm{Se}$ crystallizes isotypically to the structure of the $R E_{2} \mathrm{OF}_{2} \mathrm{Se}$ series with $R E=\mathrm{Nd}$, $\mathrm{Sm}, \mathrm{Gd}-\mathrm{Ho}$ and similar with the compounds of the $R E_{6} \mathrm{O}_{2} \mathrm{~F}_{8} \mathrm{Se}_{3}$ series with $R E=\mathrm{La}-\mathrm{Nd}$ [48], both adapting the hexagonal space group $P 6_{3} / m$ with $a=1396.82(9)$ and $c=401.08(3) \mathrm{pm}(c / a=0.287)$ for $Z=$ 6 in the case of B-type $\mathrm{La}_{2} \mathrm{OF}_{2} \mathrm{Se}$. Thus the $a$ - and $c$-axes of $\mathrm{B}-\mathrm{La}_{2} \mathrm{OF}_{2} \mathrm{Se}$ are larger than for $\mathrm{La}_{6} \mathrm{O}_{2} \mathrm{~F}_{8} \mathrm{Se}_{3}$ with $a=1394.41(9)$ and $c=403.97(2) \mathrm{pm}(c / a=0.289)$ for $\mathrm{Z}=2$, but show a smaller $c / a$-ratio. Four unit cells of B-type $\mathrm{La}_{2} \mathrm{OF}_{2} \mathrm{Se}$ in comparison to $\mathrm{La}_{6} \mathrm{O}_{2} \mathrm{~F}_{8} \mathrm{Se}_{3}$ are shown in Figure 3. There are two crystallographically different $\mathrm{La}^{3+}$ cations present in both structures. The first one (La1 in $\mathrm{B}-\mathrm{La}_{2} \mathrm{OF}_{2} \mathrm{Se}$ ) is surrounded by a square antiprism consisting of four $\mathrm{Se}^{2-}$ anions in the bottom square, but one (F2) and three $\mathrm{O}^{2-}$ anions creating the top (Figure 4a). The distances from La1 to the oxide and fluoride anions range between 243 and $251 \mathrm{pm}$, whereas to the selenide anions four times $318 \mathrm{pm}$ are found. The second one (La2) has a coordination number of nine residing in a tricapped trigonal prism erected by two $\mathrm{Se}^{2-}$, one $\mathrm{O}^{2-}$ and six $\mathrm{F}^{-}$anions (Figure $4 \mathrm{~b}$ ) with distances of $244.5 \mathrm{pm}$ to the oxide anion, between 246 and $261 \mathrm{pm}$ to the fluoride anions and again two times $318 \mathrm{pm}$ to the selenide anions. While the (F1)- anion in A-type $\mathrm{La}_{2} \mathrm{OF}_{2} \mathrm{Se}$ centers the triangular plane of three $\mathrm{La}^{3+}$ cations, in B-type $\mathrm{La}_{2} \mathrm{OF}_{2} \mathrm{Se}$ the analogous (F1) ${ }^{-}$particle is located outside of this triangle with a deflection of about $94 \mathrm{pm}$ (Figure $4 \mathrm{~d}$ ) in a distance of $246.6 \mathrm{pm}(2 \times)$ and $260.9 \mathrm{pm}$ to the $(\mathrm{La} 2)^{3+}$ anions. The (F2) ${ }^{-}$and the 
$\mathrm{O}^{2-}$ anions are in both structures of $\mathrm{La}_{2} \mathrm{OF}_{2} \mathrm{Se}$ surrounded by $\left(\mathrm{La}^{3+}\right)_{4}$ tetrahedra (Figure $4 \mathrm{c}, \mathrm{e}$ ) with distances of about $244 \mathrm{pm}$ in the oxygen and $250 \mathrm{pm}$ in the fluorine case. While the $\mathrm{Se}^{2-}$ anions in A-type $\mathrm{La}_{2} \mathrm{OF}_{2} \mathrm{Se}$ are surrounded octahedrally, they center trigonal prisms of six $\mathrm{La}^{3+}$ cations in B-type $\mathrm{La}_{2} \mathrm{OF}_{2} \mathrm{Se}$ (Figure $4 \mathrm{f}$ ) with six distances of about $318 \mathrm{pm}$. These $\left[\mathrm{SeLa}_{6}\right]^{16+}$ prisms share vertical edges to form a triple and trans-oriented triangular faces to build a chain along the $c$-axis (Figure 5). The inner channels of these chains remain empty, in B-type $\mathrm{La}_{2} \mathrm{OF}_{2} \mathrm{Se}$, but host $\mathrm{F}^{-}$-anions in $\mathrm{La}_{6} \mathrm{O}_{2} \mathrm{~F}_{8} \mathrm{Se}_{3}$ [48] to increase the coordination number of $(\mathrm{La} 1)^{3+}$ from eight to nine. Along with this the position of $\mathrm{O}^{2-}$ has to be substituted partly with $\mathrm{F}^{-}$anions to secure the charge balance of $\mathrm{La}_{6} \mathrm{O}_{2} \mathrm{~F}_{8} \mathrm{Se}_{3}$ [48]. There is also a not filled tube along the $c$-axis in B-type $\mathrm{La}_{2} \mathrm{OF}_{2} \mathrm{Se}$ and $\mathrm{La}_{6} \mathrm{O}_{2} \mathrm{~F}_{8} \mathrm{Se}_{3}$, which can be partly filled with $\mathrm{Na}^{+}$cations like in $\mathrm{NaCe}_{18} \mathrm{O}_{9} \mathrm{~F}_{19} \mathrm{Se}_{9}$ [59].
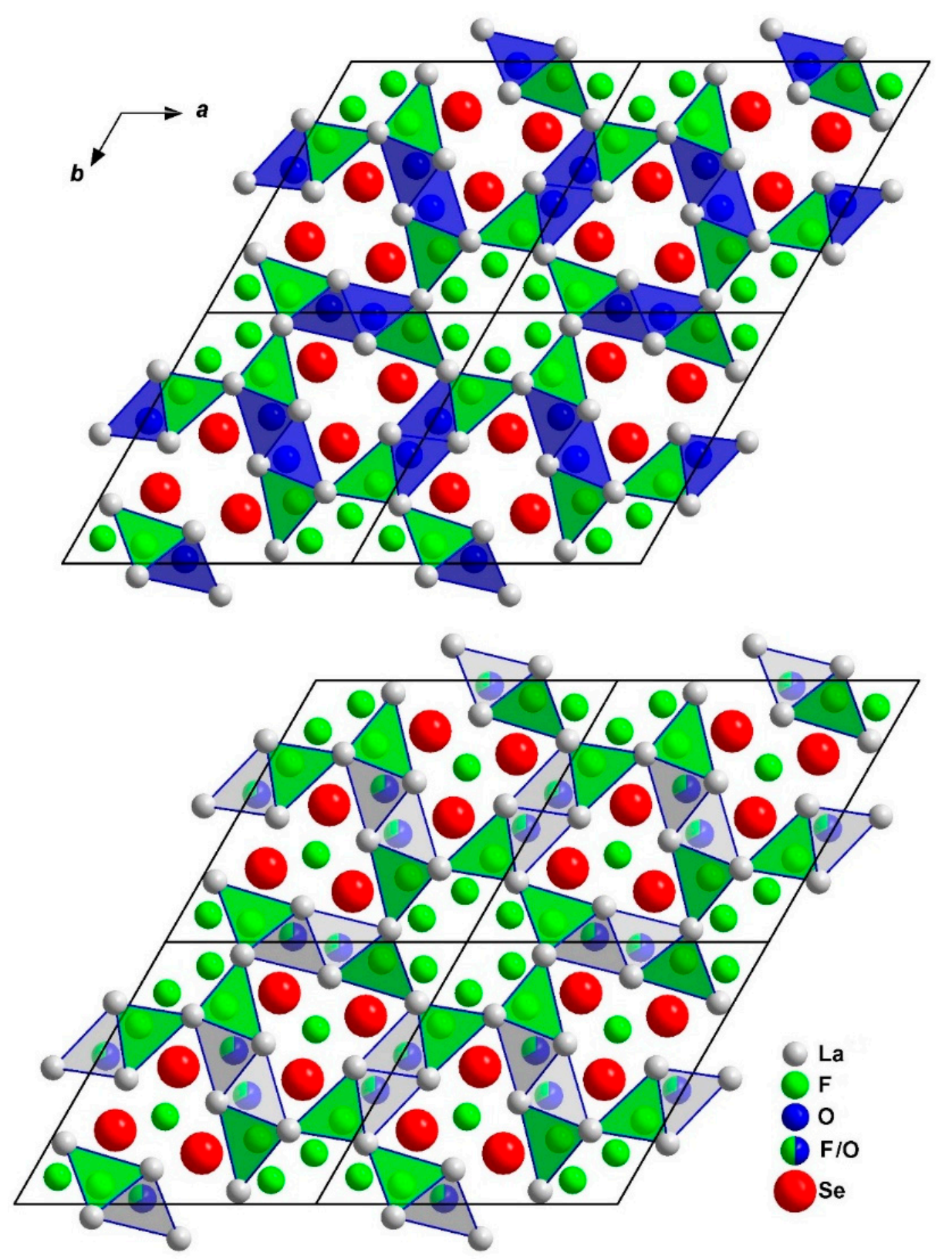

Figure 3. Comparison of the crystal structures of B-type $\mathrm{La}_{2} \mathrm{OF}_{2} \mathrm{Se}$ (top) and $\mathrm{La}_{6} \mathrm{O}_{2} \mathrm{~F}_{8} \mathrm{Se}_{3}$ (bottom) as viewed along their $c$-axes. 

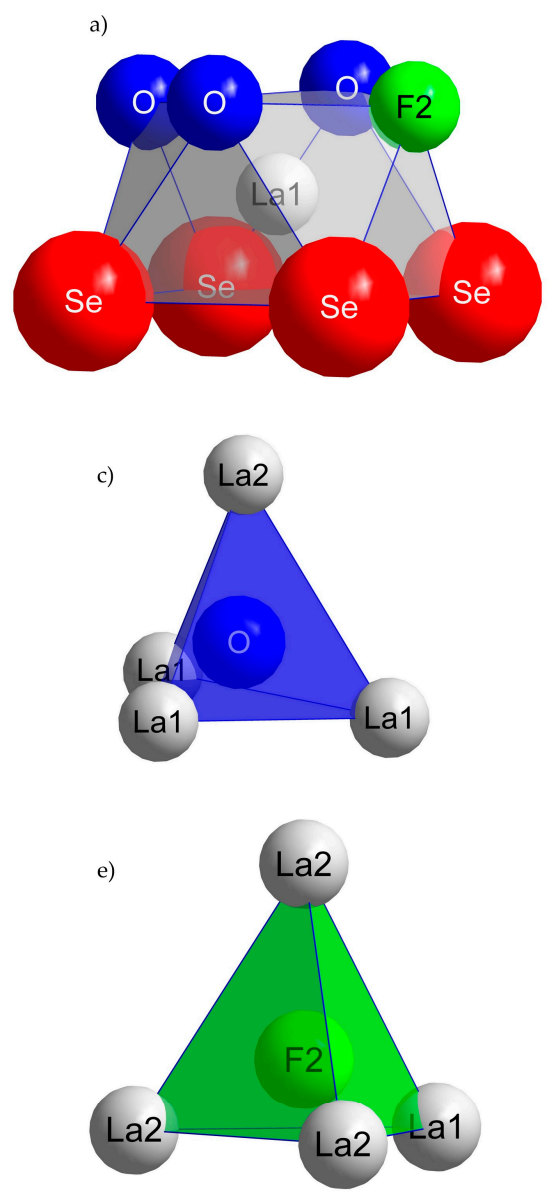

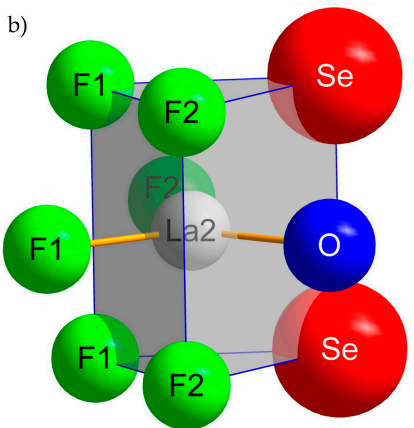

d)
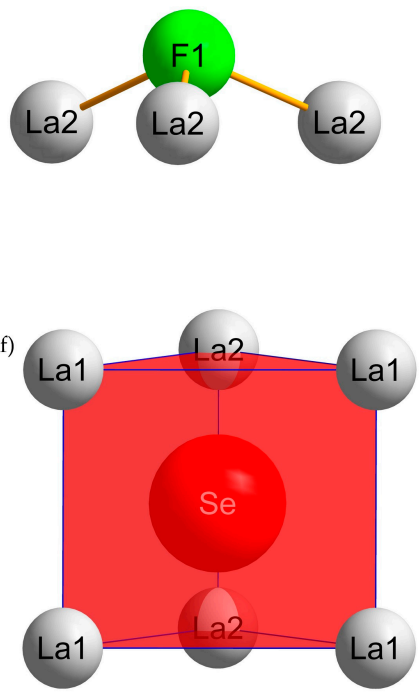

Figure 4. Coordination polyhedra in B-type $\mathrm{La}_{2} \mathrm{OF}_{2} \mathrm{Se}$.

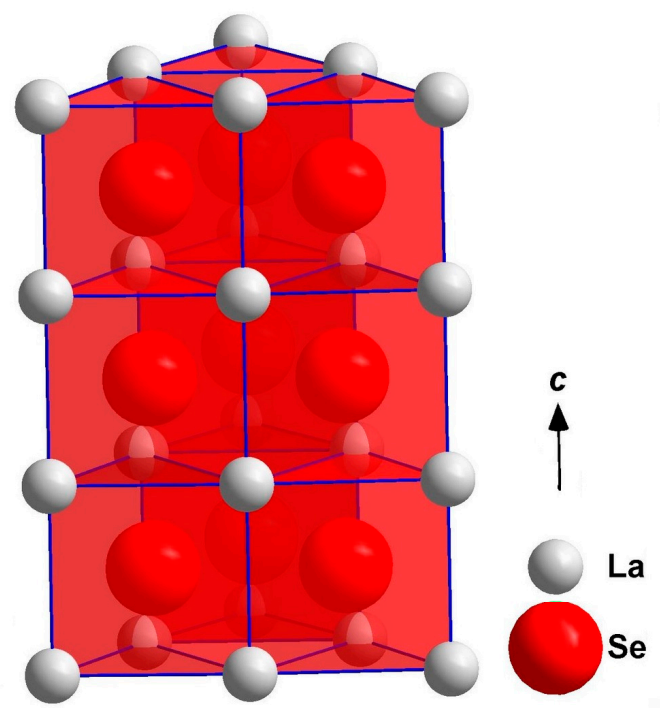

Figure 5. Connected trigonal prisms of $\mathrm{La}^{3+}$ cations surrounding the $\mathrm{Se}^{2-}$ anions in $\mathrm{B}-\mathrm{La}_{2} \mathrm{OF}_{2} \mathrm{Se}$, which build a triple chain along the $c$-axis.

\subsection{Single-Crystal Data of $A$ - and B-Type $\mathrm{La}_{2} \mathrm{OF}_{2} \mathrm{Se}$}

In Table 1 the crystallographic data of A- and B-type $\mathrm{La}_{2} \mathrm{OF}_{2} \mathrm{Se}$ as well as their determination can be seen. Tables 2 and 3 show fractional atomic coordinates and $U_{\text {eq }}$ values of both structures and 
Tables 4 and 5 some selected interatomic distances and angles in the crystal structures. The motifs of mutual adjunction in are summarized in Table 6.

Table 1. Crystallographic data of A- and B-type $\mathrm{La}_{2} \mathrm{OF}_{2} \mathrm{Se}$ and their determination.

\begin{tabular}{|c|c|c|}
\hline Compound & $\mathrm{A}-\mathrm{La}_{2} \mathrm{OF}_{2} \mathrm{Se}$ & $\mathrm{B}-\mathrm{La}_{2} \mathrm{OF}_{2} \mathrm{Se}$ \\
\hline crystal system & trigonal & hexagonal \\
\hline space group & $R \overline{3} m($ no. 166$)$ & $P 6_{3} / m$ (no. 172$)$ \\
\hline \multicolumn{3}{|l|}{ lattice parameters, } \\
\hline$a / \mathrm{pm}$ & 418.13(3) & 1396.82(9) \\
\hline$c / \mathrm{pm}$ & $4478.2(4)$ & $401.08(3)$ \\
\hline$c / a$ & 10.710 & 0.287 \\
\hline number of formula units $(Z)$ & 6 & 6 \\
\hline unit-cell volume $\left(V_{\mathrm{uc}}\right.$ in $\left.\mathrm{nm}^{3}\right)$ & $0.67804(9)$ & $0.67771(8)$ \\
\hline molar volume $\left(V_{\mathrm{m}}\right.$ in $\left.\mathrm{cm}^{3} / \mathrm{mol}\right)$ & 68.053 & 68.020 \\
\hline calculated density $\left(D_{\mathrm{x}}\right.$ in $\left.\mathrm{g} / \mathrm{cm}^{3}\right)$ & 6.036 & 6.039 \\
\hline diffractometer & IPDS (Stoe and Cie) & к-CCD (Bruker-Nonius) \\
\hline wavelength $(\lambda$ in pm) & $\operatorname{Mo}-K_{\alpha}(\lambda=71.07 \mathrm{pm})$ & $\operatorname{Mo}-K_{\alpha}(\lambda=71.07 \mathrm{pm})$ \\
\hline index range $\left( \pm h_{\max }, \pm k_{\max }, \pm l_{\max }\right)$ & $6 / 6 / 67$ & $19 / 19 / 5$ \\
\hline number of $\mathrm{e}^{-}$per unit cell $(F(000))$ & 1044 & 1044 \\
\hline absorption coefficient $\left(\mu\right.$ in $\left.\mathrm{mm}^{-1}\right)$ & 26.59 & 26.60 \\
\hline number of collected vs. unique reflections & $3237 / 383$ & $13042 / 749$ \\
\hline data-set residuals $\left(R_{\mathrm{int}} / R_{\sigma}\right)$ & $0.070 / 0.027$ & $0.097 / 0.052$ \\
\hline structure residuals $\left(R_{1} / \mathrm{w} R_{2}\right)$ & $0.026 / 0.088$ & $0.052 / 0.120$ \\
\hline goodness of fit $(\mathrm{GooF})$ & 1.072 & 1.028 \\
\hline residual electron density (max./min. in $\mathrm{e}^{-} 10^{-6} \mathrm{pm}^{-3}$ ) & $3.12 /-2.67$ & $3.57 /-1.98$ \\
\hline CSD number & 1919109 & 1919110 \\
\hline
\end{tabular}

Table 2. Fractional atomic coordinates and $U_{\text {eq }}$ values ${ }^{\mathrm{a}}$ for $\mathrm{A}-\mathrm{La}_{2} \mathrm{OF}_{2} \mathrm{Se}$.

\begin{tabular}{cccccc}
\hline Atom & Site & $x / \boldsymbol{a}$ & $y / \boldsymbol{b}$ & $z / c$ & $U_{\text {eq }} / \mathbf{p m}^{2}$ \\
\hline La1 & $6 c$ & 0 & 0 & $0.133109(14)$ & $206(3)$ \\
La2 & $6 c$ & 0 & 0 & $0.293363(14)$ & $111(2)$ \\
O & $6 c$ & 0 & 0 & $0.18868(19)$ & $248(18)$ \\
F1 & $6 c$ & 0 & 0 & $0.03591(17)$ & $178(14)$ \\
F2 & $6 c$ & 0 & 0 & $0.34832(17)$ & $171(13)$ \\
Se & $6 c$ & 0 & 0 & $0.42052(2)$ & $138(3)$ \\
\hline \multicolumn{5}{c}{$U_{\text {eq }}=1 / 3\left[U_{33}+4 / 3\left(U_{11}+U_{22}-U_{12}\right)\right][60]}$.
\end{tabular}

Table 3. Fractional atomic coordinates and $U_{\text {eq }}$ values ${ }^{\mathrm{a}}$ for $\mathrm{B}-\mathrm{La}_{2} \mathrm{OF}_{2} \mathrm{Se}$.

\begin{tabular}{cccccc}
\hline Atom & Site & $x / a$ & $y / b$ & $z / c$ & $U_{\mathbf{e q}} / \mathbf{p m}^{2}$ \\
\hline La1 & $6 h$ & $0.12574(8)$ & $0.51625(8)$ & $1 / 4$ & $231(3)$ \\
La2 & $6 h$ & $0.23351(8)$ & $0.28450(8)$ & $1 / 4$ & $239(3)$ \\
O & $6 h$ & $0.4323(7)$ & $0.4156(8)$ & $1 / 4$ & $114(19)$ \\
F1 & $6 h$ & $0.1895(9)$ & $0.0901(9)$ & $1 / 4$ & $335(24)$ \\
F2 & $6 h$ & $0.0696(8)$ & $0.3151(8)$ & $1 / 4$ & $263(21)$ \\
Se & $6 h$ & $0.48066(14)$ & $0.19870(14)$ & $1 / 4$ & $232(4)$ \\
\hline \multicolumn{5}{c}{${ }^{\mathrm{a}} U_{\text {eq }}=1 / 3\left[U_{33}+4 / 3\left(U_{11}+U_{22}-U_{12}\right)\right][60]}$. \\
\end{tabular}


Table 4. Selected interatomic distances $(d / \mathrm{pm})$ and angles $\left(\Varangle /{ }^{\circ}\right)$ in the crystal structure of A-type $\mathrm{La}_{2} \mathrm{OF}_{2} \mathrm{Se}$.

\begin{tabular}{cccccc}
\hline Distance & & $\mathbf{( d / p m )}$ & Angle & & $\left(\Varangle /^{\circ}\right)$ \\
\hline La1-O & $(3 \times)$ & 246.9 & La1-O-La1 & $(3 \times)$ & 102.1 \\
La1-O' & $(1 \times)$ & 248.9 & La1-O-La1 & $(3 \times)$ & 115.8 \\
La1-Se & $(3 \times)$ & 317.1 & La2-F1-La2 & $(3 \times)$ & 119.4 \\
La2-F1 & $(3 \times)$ & 242.1 & La2-F2-La2 & $(3 \times)$ & 103.4 \\
La2-F2 & $(1 \times)$ & 245.2 & La2-F2-La2' & $(3 \times)$ & 115.1 \\
La2-F2' & $(3 \times)$ & 266.5 & La1-Se-La1 & $(3 \times)$ & 82.5 \\
La2-Se & $(3 \times)$ & 320.9 & La1-Se-La2 & $(6 \times)$ & 98.1 \\
O-La1 & $(3 \times)$ & 246.9 & La1-Se-La2' & $(3 \times)$ & 179.2 \\
O-La1' & $(1 \times)$ & 248.9 & La2-Se-La2 & $(3 \times)$ & 81.3 \\
F1-La2 & $(3 \times)$ & 242.1 & & & \\
F2-La2 & $(1 \times)$ & 245.2 & & & \\
F2-La2' & $(3 \times)$ & 266.5 & & & \\
Se-La1 & $(3 \times)$ & 317.1 & & & \\
Se-La2 & $(3 \times)$ & 320.9 & & & \\
\hline
\end{tabular}

Table 5. Selected interatomic distances $(d / \mathrm{pm})$ and angles $\left(\Varangle /{ }^{\circ}\right)$ in the crystal structure of B-type $\mathrm{La}_{2} \mathrm{OF}_{2} \mathrm{Se}$.

\begin{tabular}{cccccc}
\hline Distance & & $(\boldsymbol{d} / \mathbf{p m})$ & Angle & & $\left(\Varangle /^{\circ}\right)$ \\
\hline La1-O & $(1 \times)$ & 243.0 & La1-O-La1 & $(2 \times)$ & 105.4 \\
La1-O' & $(2 \times)$ & 243.5 & La1-O-La1' & $(1 \times)$ & 110.9 \\
La1-F2 & $(1 \times)$ & 251.1 & La1-O-La2 & $(2 \times)$ & 109.8 \\
La1-Se & $(2 \times)$ & 318.0 & La1'-O-La2 & $(1 \times)$ & 115.3 \\
La1-Se' & $(2 \times)$ & 318.3 & La2-F1-La2' & $(2 \times)$ & 100.4 \\
La2-O & $(1 \times)$ & 244.5 & La2-F1-La2 & $(1 \times)$ & 110.9 \\
La2-F1 & $(1 \times)$ & 246.6 & La1-F2-La2 & $(2 \times)$ & 105.9 \\
La2-F1' & $(2 \times)$ & 260.9 & La1-F2-La2' & $(1 \times)$ & 112.7 \\
La2-F2 & $(2 \times)$ & 249.8 & La2-F2-La2 & $(1 \times)$ & 106.8 \\
La2-F2' & $(1 \times)$ & 253.5 & La2-F2-La2' & $(2 \times)$ & 112.5 \\
La2-Se & $(2 \times)$ & 318.3 & La1-Se-La1 & $(2 \times)$ & 78.1 \\
O-La1 & $(1 \times)$ & 243.0 & La1-Se-La1' & $(2 \times)$ & 89.8 \\
O-La1' & $(2 \times)$ & 243.5 & La1-Se-La2 & $(2 \times)$ & 82.5 \\
O-La2 & $(1 \times)$ & 244.4 & La1'-Se-La2 & $(2 \times)$ & 80.6 \\
F1-La2 & $(1 \times)$ & 246.6 & La2-Se-La2 & $(2 \times)$ & 78.1 \\
F1-La2' & $(2 \times)$ & 260.9 & & & \\
F2-La1 & $(1 \times)$ & 251.1 & & & \\
F2-La2 & $(2 \times)$ & 249.8 & & & \\
F2-La2' & $(1 \times)$ & 253.5 & & & \\
Se-La1 & $(2 \times)$ & 318.0 & & \\
Se-La1 & $(2 \times)$ & 318.3 & & \\
\hline
\end{tabular}

Table 6. Motifs of mutual adjunction in A- and B-type $\mathrm{La}_{2} \mathrm{OF}_{2} \mathrm{Se}$.

\begin{tabular}{cccccc}
\hline A-La $2 \mathbf{O F}_{2}$ Se: & & & & & \\
\hline & $\mathrm{F} 1$ & $\mathrm{~F} 2$ & $\mathrm{O}$ & $\mathrm{Se}$ & $\mathrm{C} . \mathrm{N}$. \\
$\mathrm{La} 1$ & $0 / 0$ & $0 / 0$ & $4 / 4$ & $3 / 3$ & 7 \\
$\mathrm{La} 2$ & $3 / 3$ & $4 / 4$ & $0 / 0$ & $3 / 3$ & 10 \\
C.N. & 3 & 4 & 4 & 6 & \\
\hline B-La $2 \mathrm{OF}_{2}$ Se: & & & & & \\
\hline & $\mathrm{F} 1$ & $\mathrm{~F} 2$ & $\mathrm{O}$ & $\mathrm{Se}$ & $\mathrm{C} . \mathrm{N}$. \\
$\mathrm{La} 1$ & & $1 / 1$ & $3 / 3$ & $4 / 4$ & 8 \\
La2 & & $3 / 3$ & $1 / 1$ & $2 / 2$ & 9 \\
C.N. & 3 & 4 & 4 & 6 & \\
\hline
\end{tabular}




\subsection{Energy-Dispersive X-Ray Spectrum of B-Type $\mathrm{La}_{2} \mathrm{OF}_{2} \mathrm{Se}$}

Table 7 summarizes the results of an EDXS measurement on a single crystal of B-type $\mathrm{La}_{2} \mathrm{OF}_{2} \mathrm{Se}$, which is shown in Figure 6. The content of oxygen was calculated in such a way that there was no change left in the stoichiometric composition $\mathrm{La}_{2} \mathrm{OF}_{2} \mathrm{Se}$. For this reason no error margins can be given.

Table 7. Results of an energy-dispersive X-ray spectrometer (EDXS) measurement on a single crystal of B-type $\mathrm{La}_{2} \mathrm{OF}_{2} \mathrm{Se}$.

\begin{tabular}{ccc}
\hline Element & Measured Content [wt-\%] & Theoretical Content [wt-\%] \\
\hline La & $68.4(5)$ & 67.63 \\
O & 4.15 & 3.90 \\
F & $9.66(14)$ & 9.25 \\
Se & $17.79(16)$ & 19.22 \\
\hline
\end{tabular}

It can be seen from Table 7, that the measured and the theoretical element content almost coincide. The measured carbon as shown in Figure 6 also was not considered in the calculation, since it originated from the sample preparation.

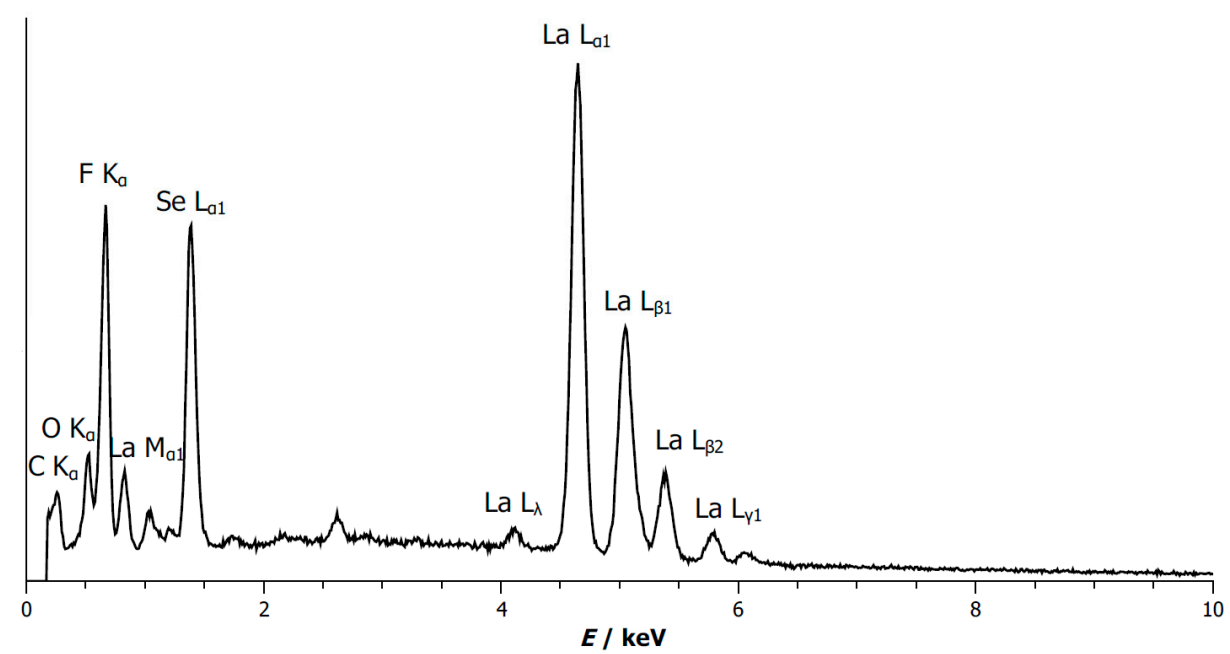

Figure 6. The energy-dispersive X-Ray spectrum (EDXS) of a single crystal of B-type $\mathrm{La}_{2} \mathrm{OF}_{2} \mathrm{Se}_{\text {. }}$

\section{Discussion}

Both crystal structures of $\mathrm{La}_{2} \mathrm{OF}_{2} \mathrm{Se}$ show striking resemblance to either $\mathrm{La}_{2} \mathrm{O}_{2} \mathrm{Se}$ and $\mathrm{La}_{2} \mathrm{~F}_{4} \mathrm{Se}$ in the trigonal A-type or $\mathrm{La}_{6} \mathrm{O}_{2} \mathrm{~F}_{8} \mathrm{Se}_{3}$ in the hexagonal B-type case. A- $\mathrm{La}_{2} \mathrm{OF}_{2} \mathrm{Se}$ displays the coordination polyhedra with the lowest $\left(\left[\mathrm{LaO}_{4} \mathrm{Se}_{3}\right]^{11-}, \mathrm{C} . \mathrm{N} .=7\right)$ and the highest coordination numbers $\left(\left[\mathrm{LaF}_{7} \mathrm{Se}_{3}\right]^{10-}\right.$, C.N. $=10)$ for both, while for B- $\mathrm{La}_{2} \mathrm{OF}_{2} \mathrm{Se}$ they range in the middle $\left(\left[\mathrm{LaO}_{3} \mathrm{FSe}_{4}\right]^{12-}\right.$, C.N. $=8$; $\left.\left[\mathrm{LaOF}_{6} \mathrm{Se}_{2}\right]^{9-}, \mathrm{C} . \mathrm{N} .=9\right)$, but carry the more diverse charges. With A- $\mathrm{La}_{2} \mathrm{OF}_{2} \mathrm{Se}(a=418.13(3), c=$ $4478.2(4) \mathrm{pm})$ being a perfect intergrowth adduct of $\mathrm{La}_{2} \mathrm{O}_{2} \mathrm{Se}(a=408.27(3), c=717.19(5) \mathrm{pm})$ [58] and $\mathrm{La}_{2} \mathrm{~F}_{4} \mathrm{Se}(a=417.86(2), c=2326.78(9) \mathrm{pm})$ [57] the occurrence of the same polyhedra does not surprise, but the $\mathrm{La}_{2} \mathrm{O}_{2} \mathrm{Se}$ compartment of $\mathrm{A}-\mathrm{La}_{2} \mathrm{OF}_{2} \mathrm{Se}$ appears a little more dilated $\left(d\left(\mathrm{La}^{3+}-\mathrm{O}^{2-}\right)=3 \times 246.9\right.$ and $\left.1 \times 248.9 \mathrm{pm}, d\left(\mathrm{La}^{3+}-\mathrm{Se}^{2-}\right)=3 \times 317.1 \mathrm{pm}\right)$ as compared to the original ternary $\left(d\left(\mathrm{La}^{3+}-\mathrm{O}^{2-}\right)=\right.$ $1 \times 241.9$ and $\left.3 \times 243.9 \mathrm{pm}, d\left(\mathrm{La}^{3+}-\mathrm{Se}^{2-}\right)=3 \times 313.3 \mathrm{pm}\right)$ [58], whereas the $\mathrm{La}_{2} \mathrm{~F}_{4} \mathrm{Se}$ part $\left(d\left(\mathrm{La}^{3+}-\mathrm{F}^{-}\right)=\right.$ $3 \times 242.1,1 \times 245.2$ plus $\left.3 \times 266.5 \mathrm{pm}, d\left(\mathrm{La}^{3+}-\mathrm{Se}^{2-}\right)=3 \times 320.9 \mathrm{pm}\right)$ outstandingly agrees with $\mathrm{La}_{2} \mathrm{~F}_{4} \mathrm{Se}\left(d\left(\mathrm{La}^{3+}-\mathrm{F}^{-}\right)=3 \times 241.9,1 \times 242.9\right.$ plus $\left.3 \times 266.5 \mathrm{pm}, d\left(\mathrm{La}^{3+}-\mathrm{Se}^{2-}\right)=3 \times 319.7 \mathrm{pm}\right)[57]$ itself. Hence the Madelung part of the lattice energy (MAPLE) [61-63] shows a slightly better agreement between the value for $\mathrm{A}-\mathrm{La}_{2} \mathrm{OF}_{2} \mathrm{Se}(12141 \mathrm{~kJ} / \mathrm{mol})$ and the sum of the ternaries $\left(\mathrm{La}_{2} \mathrm{O}_{2} \mathrm{Se}: 13477\right.$ $\left.\mathrm{kJ} / \mathrm{mol}, \mathrm{La}_{2} \mathrm{~F}_{4} \mathrm{Se}: 11045 \mathrm{~kJ} / \mathrm{mol}\right)$ according to $1 / 2 \times \operatorname{MAPLE}\left(\mathrm{La}_{2} \mathrm{O}_{2} \mathrm{Se}\right)+1 / 2 \times \operatorname{MAPLE}\left(\mathrm{La}_{2} \mathrm{~F}_{4} \mathrm{Se}\right)=$ 
$6739+5523=12262 \mathrm{~kJ} / \mathrm{mol}$ in comparison with B-La ${ }_{2} \mathrm{OF}_{2} \mathrm{Se}(12111 \mathrm{~kJ} / \mathrm{mol})$. The latter, B- $\mathrm{La}_{2} \mathrm{OF}_{2} \mathrm{Se}$ ( $a=1396.82(9), c=401.08(3) \mathrm{pm})$, has a lot more in common with $\mathrm{La}_{6} \mathrm{O}_{2} \mathrm{~F}_{8} \mathrm{Se}_{3}(a=1394.41(9), c=$ $402.96(3) \mathrm{pm})[48]$, as the similar interatomic distances $\left(d\left(\mathrm{La}^{3+}-\mathrm{O}^{2-}\right)=243-245 \mathrm{pm}, d\left(\mathrm{La}^{3+}-\mathrm{F}^{-}\right)=\right.$ 247-253 plus $261 \mathrm{pm}, d\left(\mathrm{La}^{3+}-\mathrm{Se}^{2-}\right)=318-319 \mathrm{pm}$ versus $d\left(\mathrm{La}^{3+}-\mathrm{O}^{2-}\right)=244-252 \mathrm{pm}, d\left(\mathrm{La}^{3+}-\mathrm{F}^{-}\right)=$ $\left.245-256 \mathrm{pm}, d\left(\mathrm{La}^{3+}-\mathrm{Se}^{2-}\right)=316-318 \mathrm{pm}\right)$ prove, in spite of some mixed occupation of $\mathrm{O}^{2-}$ and $\mathrm{F}^{-}$ anions in tetrahedral surrounding of $\mathrm{La}^{3+}$ cations in hexagonal $\mathrm{La}_{6} \mathrm{O}_{2} \mathrm{~F}_{8} \mathrm{Se}_{3}$. The slightly higher density of $6.039 \mathrm{~g} / \mathrm{cm}^{3}$ for B- $-\mathrm{La}_{2} \mathrm{OF}_{2} \mathrm{Se}$ versus $6.036 \mathrm{~g} / \mathrm{cm}^{3} \mathrm{~A}-\mathrm{La}_{2} \mathrm{OF}_{2} \mathrm{Se}$ should predestine the B-type structure of $\mathrm{La}_{2} \mathrm{OF}_{2} \mathrm{Se}$ to be the high-pressure form or the A-type structure to represent the high-temperature modification of $\mathrm{La}_{2} \mathrm{OF}_{2} \mathrm{Se}$, which needs to become verified as soon as we shall have phase-pure samples in hands.

Supplementary Materials: The CIF of the title compounds are available online at http://www.mdpi.com/20734352/9/9/435/s1, or in the ICSD with the number 1919109 for A-type or 1919110 for B-type.

Author Contributions: H.G. synthesized the A-type form of $\mathrm{La}_{2} \mathrm{OF}_{2}$ Se and C.B. the B-type. H.G. and T.S. solved the crystal structure of A- $\mathrm{La}_{2} \mathrm{OF}_{2} \mathrm{Se}$ and C.B. and T.S. of the B-type. T.S. contributed the reagents, the materials, the scientific equipment and the infrastructure. C.B. wrote the paper and T.S. reviewed it.

Funding: This research was funded by the State of Baden-Württemberg (Stuttgart) and the Deutsche Forschungsgemeinschaft (DFG, Bonn).

Acknowledgments: We thank Falk Lissner for the single-crystal X-ray diffraction measurements and Felix C. Goerigk for the electron-beam microprobe experiment.

Conflicts of Interest: The authors declare no conflict of interest.

\section{References}

1. Folchnandt, M.; Schleid, T. Single Crystals of C-La $\mathrm{Se}_{3}, \mathrm{C}-\mathrm{Pr}_{2} \mathrm{Se}_{3}$, and C-Gd $\mathrm{Se}_{3}$ with Cation-Deficient $\mathrm{Th}_{3} \mathrm{P}_{4}$-Type Structure. Z. Anorg. Allg. Chem. 2001, 627, 1411-1413. [CrossRef]

2. Schneck, C.; Höss, P.; Schleid, T. C-type $\mathrm{Nd}_{2} \mathrm{Se}_{3}$. Acta Crystallogr. Sect. E Struct. Rep. Online 2009, 65, i20. [CrossRef]

3. Folchnandt, M.; Schneck, C.; Schleid, T. Über Sesquiselenide der Lanthanoide: Einkristalle von $\mathrm{Ce}_{2} \mathrm{Se}_{3}$ im C-, $\mathrm{Gd}_{2} \mathrm{Se}_{3}$ im U- und $\mathrm{Lu}_{2} \mathrm{Se}_{3}$ im Z-Typ. Z. Anorg. Allg. Chem. 2004, 630, 149-155. [CrossRef]

4. Prokof'ev, A.V.; Shelykh, A.I.; Golubkov, A.V.; Sharenkova, N.V. Preparation and optical properties of $\mathrm{Ln}_{2} \mathrm{Se}_{3}$ rare-earth selenides. Inorg. Mater. 1994, 30, 326-327.

5. Grundmeier, T.; Urland, W. Zur Polymorphie von $\mathrm{Sm}_{2} \mathrm{Se}_{3}$. Z. Anorg. Allg. Chem. 1995, 621, $1977-1979$. [CrossRef]

6. Julien Pouzol, M.; Guittard, M. Les phases cubiques de type $\mathrm{Th}_{3} \mathrm{P}_{4}$ dans les systèmes $\mathrm{Cu}_{2} \mathrm{Se}_{-} \mathrm{L}_{2} \mathrm{Se}_{3}$ et $\mathrm{Ag}_{2} \mathrm{Se}$ - $\mathrm{L}_{2} \mathrm{Se}_{3}$. Bull. Soc. Chim. Fr. 1968, 35, 2293-2295.

7. Julien-Pouzol, M.; Guittard, M. Etude cristallochimique des combinaisons ternaires cuivre-terre rare soufre ou selenium, situees le long des binaires $\mathrm{Cu}_{2} \mathrm{X}-\mathrm{L}_{2} \mathrm{X}_{3}$. Ann. Chim. France 1972, 7, 253-264.

8. Golabi, S.M.; Flahaut, J.; Domange, L. Compounds of the $\mathrm{Th}_{3} \mathrm{P}_{4}$ type formed between rare-earth selenides and alkaline-earth selenides. Compt. Rend. Hebd. Acad. Sci. 1964, 259, 820-822.

9. Dudnik, E.M.; Lashkarev, G.V.; Paderno, Y.B.; Obolonchik, V.A. Thermal expansion of the chalcogenides of rare-earth metals. Inorg. Mater. 1966, 2, 833-836.

10. Loriers, J.; Suchet, J.; Weill, G.; Collin, G. Structure, susceptibilité magnétique et conductibilité thermique de quelques séléniures ternaires d'argent et de terres rares. Compt. Rend. Hebd. Acad. Sci. 1965, 35, 2219-2222.

11. Miller, J.F.; Matson, L.K.; Himes, R.C. Studies on the selenides and tellurides of selected rare-earth metals. In Proceedings of the Conference on Rare Earths Research, Glenwood Springs, CO, USA, 15-16 February 1961; pp. 233-248.

12. Pribyl'skii, N.Y.; Gamidov, R.S. The $\mathrm{Cu}_{2} \mathrm{Se}-\mathrm{Pr}_{2} \mathrm{Se}_{3}$ system. Russ. J. Inorg. Chem. 1984, 11, 1707-1708.

13. Efendiev, G.K.; Karaev, Z.S.; Nasibov, I.O. About the interaction of selenides $\mathrm{A}(\mathrm{III})_{2} \mathrm{~B}(\mathrm{VI})_{3}$ of neodymium and gallium. Azerb. Khim. Zh. 1964, 4, 111-114. 
14. Pribyl'skaya, N.Y.; Eliseev, A.A.; Pribyl'skii, N.Y.; Gamidov, R.S. Homogeneity regions of lanthanide selenides with a $\mathrm{Th}_{3} \mathrm{P}_{4}$ structure. Russ. J. Inorg. Chem. 1984, 3, 451-452.

15. Holtzberg, F.; Okaya, Y.; Stemple, N.R. Th3P4 type rare earth compounds. In Proceedings of the Annual Meeting of American Crystallographic Association, Gatlinburg, TN, USA, 27 June-2 July 1965; p. 46.

16. Guittard, M.; Benacerraf, A.; Flahaut, J. Les seleniures $\mathrm{L}_{2} \mathrm{Se}_{3}$ et $\mathrm{L}_{3} \mathrm{Se}_{4}$ des elements des terres rares. Ann. Chim. France 1964, 9, 25-34.

17. Flahaut, J.; Laruelle, P.; Pardo, M.P.; Guittard, M. Les sulfures, seleniures et tellurures $\mathrm{L}_{2} \mathrm{X}_{3}$ de terres rares, d'yttrium et de scandium orthorhombiques du type $\mathrm{Sc}_{2} \mathrm{~S}_{3}$. Bull. Soc. Chim. Fr. 1965, 32, 1399-1404.

18. Holtzberg, F.; McGuire, T.R.; Methfessel, S.; Suits, J.C. Ferromagnetism in Rare-Earth Group VA and VIA Compounds with $\mathrm{Th}_{3} \mathrm{P}_{4}$ Structure. J. Appl. Phys. 1964, 35, 1033-1038. [CrossRef]

19. Pribyl'skii, N.Y.; Gamidov, R.S.; Vasil'eva, I.G. Phase equilibria in the Cu-Gd-Se system. Izv. Sibirsk. Otdel. Akad. Nauk SSSR Ser. Khim. Nauk 1983, 1983, 51-54.

20. Eatough, N.L.; Webb, A.W.; Hall, H.T. High-pressure $\mathrm{Th}_{3} \mathrm{P}_{4}$-type polymorphs of rare earth sesquichalcogenides. Inorg. Chem. 1969, 8, 2069-2071. [CrossRef]

21. Grundmeier, T.; Urland, W. Zur Kristallstruktur von $\mathrm{Tb}_{2} \mathrm{Se}_{3}$. Z. Anorg. Allg. Chem. 1997, 623, $1744-1746$. [CrossRef]

22. Range, K.J.; Leeb, R. Die Kristallstruktur von $\mathrm{Dy}_{2} \mathrm{Se}_{3}$. Z. Naturforsch. 1976, 31 b, 685-686. [CrossRef]

23. Guittard, M.; Flahaut, J.; Domange, L. Seleniures d'yttrium, de gadolinium, de dysprosium et d'erbium. Compt. Rend. Hebd. Acad. Sci. 1963, 256, 427-429.

24. Slovyanskikh, V.K.; Kuznetsov, N.T.; Gracheva, N.V. Lanthanide selenides Ln $\mathrm{Se}_{1.4+-\mathrm{x}}$ of the yttrium subgroup. Russ. J. Inorg. Chem. 1982, 27, 745-746.

25. Kuznetsov, N.T.; Slovyanskikh, V.K.; Gracheva, N.V. The compounds $\mathrm{Dy}_{2} \mathrm{Se}_{3}$ and USe 3 . Russ. J. Inorg. Chem. 1980, 25, 1130-1132.

26. Eliseev, A.A.; Sadovskaya, O.S.; Tam, N.V. X-ray investigation of europium selenides. Inorg. Mater. 1975, 11, 361-364.

27. Urland, W.; Person, H. Zur Kristallstruktur von $\mathrm{Ho}_{2} \mathrm{Se}_{3} / \mathrm{On}$ the Crystal Structure of $\mathrm{Ho}_{2} \mathrm{Se}_{3}$. Z. Naturforsch. 1998, 53 b, 900-902. [CrossRef]

28. Range, K.J.; Eglmeier, C. Crystal data for rare earth sesquiselenides $\mathrm{Ln}_{2} \mathrm{Se}_{3}(\mathrm{Ln} \equiv \mathrm{Ho}, \mathrm{Er}, \mathrm{Tm}, \mathrm{Yb}, \mathrm{Lu})$ and structure refinement of $\mathrm{Er}_{2} \mathrm{Se}_{3}$. J. Less-Common Met. 1991, 171, L27-L30. [CrossRef]

29. Fang, C.M.; Meetsma, A.; Wiegers, G.A. Crystal structure of erbium sesquiselenide, $\mathrm{Er}_{2} \mathrm{Se}_{3}$. J. Alloy. Compd. 1995, 218, 224-227. [CrossRef]

30. Assoud, A.; Kleinke, H. Ytterbium sesquiselenide $\mathrm{Yb}_{2} \mathrm{Se}_{3}$. Acta Crystallogr. Sect. E Struct. Rep. Online 2003, 59, i103-i104. [CrossRef]

31. Flahaut, J.; Domange, L.; Guittard, M.; Pardo, M.P. Etude cristallographique des seleniures et des tellures des terres rares orthorhombiques, de type $\mathrm{U}_{2} \mathrm{~S}_{3}$. Bull. Soc. Chim. Fr. 1965, 32, 326-327.

32. Filatkina, V.S.; Kustova, G.N.; Batsanov, S.S. X-ray diffraction and IR spectroscopic investigation of selenidoand telluridofluorides of neodymium. Russ. Chem. Bull. 1972, 21, 2107-2110. [CrossRef]

33. Dung, N.H. Stucture cristalline de la variete alpha du fluoroseleniure de lanthane LaSeF. Bull. Soc. Fr. Mineral. Cristallogr. 1973, 96, 41-43.

34. Dung, N.H. Etude structurale du tetrafluoroseleniure de cerium $\mathrm{Ce}_{2} \mathrm{SeF}_{4}$. Bull. Soc. Fr. Mineral. Cristallogr. 1973, 96, 44-47.

35. Zimmermann, D.D.; Schleid, T. Synthesis and crystal structures of the dimorphic holmium(III) fluoride selenide HoFSe. Z. Kristallogr. Suppl. 2014, 34, 139.

36. Zimmermann, D.D. Synthese, Charakterisierung Sowie Erweiterung von Ternären und Quaternären Seltenerdmetall-Verbindungen mit Fluoridhaltigen Gittern Unter Chalkogenidischen Einflüssen. Ph.D. Thesis, University Stuttgart, Stuttgart, Germany, 2016.

37. Dung, N.H.; Dagron, C.; Laruelle, P. Etude structurale des polytypes à deux anions LSeF (L = Y, Ho, Er). I. Structure cristalline du polytype orthorhombique à six couches du fluoroséléniure d'erbium ErSeF 6 O. Acta Crystallogr. Sect B Struct. Sci. 1975, 31, 514-518. [CrossRef] 
38. Dung, N.H.; Laruelle, P. Etude stucturale des polytypes à deux anions LSeF (L = Y, Ho, Er). IV. Structure cristalline du polytype monoclinique à huit couches du fluoroséléniure d'ytrrium 'YSeF' $8 \mathrm{M}$. Acta Crystallogr. Sect. B Struct. Sci. 1977, 33, 3360-3363. [CrossRef]

39. Dung, N.H.; Dagron, C.; Laruelle, P. Etude structurale des polytypes à deux anions LSeF (L = Y, Ho, Er). II. Structure cristalline du fluoroséléniure d'yttrium YSeF, polytype monoclinique à quatre couches $4 \mathrm{M}$. Acta Crystallogr. Sect. B Struct. Sci. 1975, 31, 519-521. [CrossRef]

40. Dung, N.H. Structure cristalline du fluoroséléniure d'yttrium orthorhombique YSeF 1 O. Acta Crystallogr. Sect B Struct. Sci. 1973, 29, 2095-2097. [CrossRef]

41. Weber, F.A.; Schurz, C.M.; Frunder, S.; Kuhn, C.F.; Schleid, T. The Short Series of the Oxygen-Poor Lanthanide Oxide Selenides $\mathrm{M}_{10} \mathrm{OSe}_{14}$ with $\mathrm{M}=\mathrm{La}-\mathrm{Nd}$. Crystals 2012, 2, 1136-1145. [CrossRef]

42. Weber, F.A.; Schleid, T. Vier Oxidselenide des Praseodyms: $\operatorname{Pr}_{10} \mathrm{OSe}_{14}, \operatorname{Pr}_{2} \mathrm{OSe}_{2}, \operatorname{Pr}_{2} \mathrm{O}_{2} \mathrm{Se}_{\mathrm{und}} \mathrm{Pr}_{4} \mathrm{O}_{4} \mathrm{Se}_{3}$. Z. Anorg. Allg. Chem. 2001, 627, 1383-1388. [CrossRef]

43. Tougait, O.; Ibers, J.A. Gd ${ }_{2} \mathrm{OSe}_{2}$. Acta Crystallogr. Sect. C Cryst. Struct. Commun. 2000, 56, 623-624. [CrossRef]

44. Eick, H.A. The crystal structure and lattice parameters of some rare earth mono-seleno oxides. Acta Crystallogr. 1960, 13, 161. [CrossRef]

45. Киряков, А.С.; Тарасенко, М.С. Синтез твердых растворов состава: Y1,98RE0,02O2Se (RE = Ce-Nd, Sm)-И ИЗУЧЕНИЕ ИХФОТОФИЗИЧЕСКИХСВОЙСТВ. МНСК-2018: Химия. 2018, p. 80. Available online: https://issc.nsu.ru/upload/Химия_MHCK-2017.pdf (accessed on 19 August 2019).

46. Zimmermann, D.D.; Schleid, T. $\mathrm{Ho}_{3} \mathrm{OFSe}_{3}$ and $\mathrm{Ho}_{3} \mathrm{OF}_{3} \mathrm{Se}_{2}$ : Two surprising new structure types for rare-earth metall(III) oxide fluoride selenides. Z. Kristallogr. Suppl. 2014, 34, 138.

47. Zimmermann, D.D.; Schleid, T. $\mathrm{Ce}_{6} \mathrm{O}_{4} \mathrm{~F}_{4} \mathrm{Se}_{3}$ : A New Variant for Lanthanoid Oxide Fluoride Selenides. Z. Anorg. Allg. Chem. 2014, 2351. [CrossRef]

48. Zimmermann, D.D.; Grossholz, H.; Wolf, S.; Janka, O.; Müller, A.C.; Schleid, T. Two Hexagonal Series of Lanthanoid(III) Oxide Fluoride Selenides: $\mathrm{M}_{6} \mathrm{O}_{2} \mathrm{~F}_{8} \mathrm{Se}_{3}(\mathrm{M}=\mathrm{La}-\mathrm{Nd})$ and $\mathrm{M}_{2} \mathrm{OF}_{2} \mathrm{Se}(\mathrm{M}=\mathrm{Nd}, \mathrm{Sm}, \mathrm{Gd}-\mathrm{Ho})$. Z. Anorg. Allg. Chem. 2015, 641, 1926-1933. [CrossRef]

49. Grossholz, H.; Zimmermann, D.D.; Janka, O.; Schleid, T. Oxidfluoridsulfide der Lanthanoide vom Formeltyp $\mathrm{M}_{6} \mathrm{O}_{2} \mathrm{~F}_{8} \mathrm{~S}_{3}(\mathrm{M}=\mathrm{La}-\mathrm{Nd}, \mathrm{Sm}, \mathrm{Gd}) / O x i d e$ Fluoride Sulfides of the Lanthanoids with the Formula $\mathrm{M}_{6} \mathrm{O}_{2} \mathrm{~F}_{8} \mathrm{~S}_{3}$ (M = La-Nd, Sm, Gd). Z. Naturforsch. 2013, 68b, 751-760. [CrossRef]

50. Grossholz, H.; Janka, O.; Schleid, T. Oxide Fluoride Sulfides of the Lanthanoids with the Formula $\mathrm{M}_{3} \mathrm{OF}_{5} \mathrm{~S}$ $(\mathrm{M}=\mathrm{Nd}, \mathrm{Sm}, \mathrm{Gd}-\mathrm{Ho})$. Z. Naturforsch. 2011, 666, 213-220. [CrossRef]

51. Grossholz, H.; Schleid, T. $\mathrm{Dy}_{3} \mathrm{OF}_{5} \mathrm{~S}$ : Das erste Oxidfluoridsulfid eines Lanthanoids. Z. Anorg. Allg. Chem. 2002, 628, 1012-1016. [CrossRef]

52. Müller, A.C.; Janka, O.; Zimmermann, D.D.; Schleid, T. A-YFS and $\mathrm{Y}_{3} \mathrm{OF}_{5} \mathrm{~S}$ : oxygen-free and oxygen-containing yttrium fluoride sulfides. Z. Anorg. Allg. Chem. 2014, 640, 2352.

53. Pauwels, D.; Demourgues, A.; Laronze, H.; Gravereau, P.; Guillen, F.; Isnard, O.; Tressaud, A. Structural features of new rare earth-based mixed anions $(\mathrm{O}, \mathrm{S}, \mathrm{F})$ compounds: relationships between optical absorption and rare earth environment. Solid State Sci. 2002, 4, 1471-1479. [CrossRef]

54. Strobel, S.; Müller, A.C.; Schleid, T. The Crystal Structures of $\mathrm{Er}_{3} \mathrm{OFS}_{3}$ and $\mathrm{Er}_{3} \mathrm{OF}_{3} \mathrm{~S}_{2}$ : Two Erbium Oxide Fluoride Sulfides with Condensed Tetrahedral [ $\left.\mathrm{ZEr}_{4}\right]$ Units $(\mathrm{Z}=\mathrm{O}$ and F). Z. Anorg. Allg. Chem. 2009, 635, 1940-1946. [CrossRef]

55. Sheldrick, G.M. Program Suite for the Solution and Refinement of Crystal Structures; University Göttingen: Göttingen, Germany, 1997.

56. Sheldrick, G.M. A short history of SHELX. Acta Crystallogr. Sect. A 2008, 64, 112-122. [CrossRef]

57. Wolf, S. Darstellung und Charakterisierung Ternärer und Quaternärer Selten-Erd-Metall-Fluoride und-Oxidfluoride mit Elementen der 16. und 17. Gruppe. Staatsexamensarbeit; University Stuttgart: Stuttgart, Germany, 2012.

58. Weber, F.A. Präparative Studien in den Mehrstoffsystemen Selten-Erd-Metall-Selen bzw. Tellur und Sauerstoff. Ph.D. Thesis, University Stuttgart, Stuttgart, Germany, 1999.

59. Buyer, C.; Wolf, S.; Schleid, T. $\mathrm{NaCe}_{18} \mathrm{O}_{9} \mathrm{~F}_{19} \mathrm{Se}_{9}$ : A Sodium-Containing Compound in the $\mathrm{Ce}_{2} \mathrm{OF}_{2} \mathrm{Se}-\mathrm{Ce}_{6} \mathrm{O}_{2} \mathrm{~F}_{8} \mathrm{Se}_{3}$ System. Z. Kristallogr. Suppl. 2019, 39, 95.

60. Fischer, R.X.; Tillmanns, E. The equivalent isotropic displacement factor. Acta Crystallogr. Sect. C Cryst. Struct. Commun. 1988, 44, 775-776. [CrossRef]

61. Hoppe, R. Madelung Constants. Angew. Chem. Int. Ed. Engl. 1966, 5, 95-106. [CrossRef] 
62. Hoppe, R. The Coordination Number-An “Inorganic Chameleon". Angew. Chem. Int. Ed. Engl. 1970, 9, 25-34. [CrossRef]

63. Hübenthal, R.; Hoppe, R. MAPLE; Program for the Calculation of the Madelung Part of Lattice Energy; University of Gießen: Gießen, Germany, 1993.

(C) 2019 by the authors. Licensee MDPI, Basel, Switzerland. This article is an open access article distributed under the terms and conditions of the Creative Commons Attribution (CC BY) license (http://creativecommons.org/licenses/by/4.0/). 